\title{
WHAT WILL BE HAPPEN WITH NEW MANDALA TRANSFORMATION?
}

\author{
Sevenpri Candra \\ Jurusan Manajemen, Fakultas Ekonomi dan Bisnis, Bina Nusantara University \\ Jln. KH Syahdan No. 9, Kemanggisan, Palmerah, Jakarta Barat 11480 \\ seven@binus.ac.id
}

\begin{abstract}
Today's business in airline is getting high. The competitive for pricing and services is getting tight. Each airlines battle to get profit growth. This problem is also feeling by Mandala Airlines. They conduct changing through inside and outside organization. They are reshaping the structure of their business to win the battle. Since mid of 2007, Mandala Airlines doing transformation. Under new management, there are full of confidence to changing. Changing their image into new modern airlines with international standard. What will be happen with New Mandala Transformation? Are they successfully doing transformation and can survive in this competition?
\end{abstract}

Keywords: transformation, airlines, organization change

\begin{abstract}
ABSTRAK
Bisnis maskapai penerbangan sekarang ini cukup tinggi. Kompetisi harga dan pelayanan cukup ketat, masing-masing maskapai penerbangan berlomba mencapai laba. Permasalahan ini juga dirasakan oleh Mandala Airlines. Mereka menerapkan perubahan melalui internal dan eksternal organisasi. Mereka membentuk kembali struktur bisnis untuk memenangkan persaingan. Sejak tengah tahun 2007, Mandala Airlines melakukan transformasi. Di bawah manajemen baru, tersedia berbagai kesempatan untuk berubah: mengubah citra mereka menjadi sebuah citra maskapai penerbangan modern dengan standar internasional. Apa yang akan terjadi dengan transformasi baru Mandala? Apakah mereka akan sukses melakukan transformasi dan bisa bertahan di kompetisi ini?
\end{abstract}

Kata kunci: transformasi, maskapai penerbangan, perubahan organisasi 


\section{INTRODUCTION}

In today's business, each company should be aware of changes that happened in the outside. They should manage well with the rapid change of environment. Especially in airlines, organization should be change to win the competition and improve their performance. The key successful tactics for building transformations can be organized in four well-known transformation design themes: aspirations (well-defined stretch targets), leadership (strong CEO involvement), process (a clear structure for the transformation), and energy (for instance, efforts to ensure frontline ownership of change). It's not enough simply to bring these tactics to bear, of course; executing them well is the other half of the battle (Isren, Meaney, \& Wilson, 2009).

Based on McKinsey \& Company, if organizational transformations are to succeed, change can't be thought of as a single, standardized process. The McKinsey Global survey results highlight several important tactics that organizations use to transform themselves successfully. Setting clear and high aspirations for change is the most significant. A second tactic is engaging the whole company in the change effort through a wide variety of means; a highly involved and visible CEO is important, but successful companies also use various other communication and accountability methods to keep people involved - far more methods than unsuccessful companies use. Also notable: successful companies are far likelier to communicate the need for change in a positive way, encouraging employees to build on success rather than focusing exclusively on fixing problems (McKinsey \& Company, July 2008).

Four key functions collectively define a successful role for the CEO in a transformation (Aiken \& Keller, 2006): (1) Making the transformation meaningful. People will go to extraordinary lengths for causes they believe in, and a powerful transformation story will create and reinforce their commitment. The ultimate impact of the story depends on the CEO's willingness to make the transformation personal, to engage others openly, and to spotlight successes as they emerge. (2) Rolemodeling desired mind-sets and behavior. Successful CEOs typically embark on their own personal transformation journey. Their actions encourage employees to support and practice the new types of behavior. (3) Building a strong and committed top team. To harness the transformative power of the top team, CEOs must make tough decisions about who has the ability and motivation to make the journey. (4) Relentlessly pursuing impact. There is no substitute for CEOs rolling up their sleeves and getting personally involved when significant financial and symbolic value is at stake.

\section{History of Mandala Airlines}

PT Mandala Airlines was founded on April 17, 1969. The founders were Col. Sofjar, Maj. Gen. Raden Soerjo, Adil Aljol, Maj. (Air Force) Soegandi Partosoegondo, Kasbi Indradjanoe and Darwin Ramli. The airline was owned by PT Dharma Kencana Sakti, which in turn was the commercial arm of Yayasan Dharma Putra Kostrad, a foundation linked to Kostrad, the strategic reserve command of the Indonesian army. The airline was named after Operation Mandala, the military operations to incorporate West Papua into Indonesia. The name also refers to mandala, a Sanskrit term for a diagram symbolizing the universe, which is used as the logo of the corporation.

In its early years Mandala Airlines operated flights between Jakarta and destinations in eastern Indonesia, such as Ambon, Gorontalo, Kendari, Makassar and Manado. In 1972 Mandala took over Seulawah Air Service (another military-owned airline), which flew to cities in western Indonesia, such as Banda Aceh, Banjarmasin, Medan, Padang, Palembang, Pekanbaru and Pontianak, giving the airline a national coverage. 
Under military management, Mandala Airlines kept a relatively quiet existence as a secondtier airline. In 1992, it retired the last of its aged turboprop fleet and replaced them with leased second hand jet aircraft. In 2001, it suffered a financial scandal, in which no less than IDR 135.5 billion (about USD 13.5 million) was stolen from the company. Despite being awarded as Indonesia's "Most Potential Brand in Airlines Service" in 2002, Mandala found it hard to compete with other recentlyemerged Indonesian airlines. In 2005, Mandala experienced a high profile accident in Medan. At about the same time, Mandala, as a legacy carrier, could not compete effectively with startup airlines. Mandala was sold to Cardig International acquired the airline for IDR 300 billion (USD 34 million) in April 2006. Indigo Partners (USA) acquired 49\% of Cardig's shares in October 2006 with the strategic goal to grow Mandala into the leading airline in Indonesia and the region. Cardig International specializes in JV companies focused on the aviation sector i.e. airport services, integrated logistics solutions, in-flight catering, cargo airlines, international courier, passengers airlines and currently has investments in 10 companies. Indigo Partners specialize in Airline and Transport sector investments and has a stake in Spirit Airlines (USA), Wizz (Europe), Tiger (Singapore), Abnanova Airlines (Russia) and, Mandala Airlines (Indonesia). Both investors recognize the huge potential of Indonesia's market and the requirement for a well run modern generation airline.

\section{DISCUSSION}

\section{The Journey into New Mandala Airlines}

"We call it the New Mandala. Because we have a new investor, new aircraft, and new management. In 2008 we focused on communications, networking and branding, "said Warwick Brady, CEO of Mandala. As a CEO of Mandala Airlines, at that time Warwick has prepared a working agenda. For the short term, the target is able to communicate aggressively with customers and increase frequency of flights some routes. While the medium-term agenda: the company's growth of $25 \%$ per year. The long term goal to be the dominant airline in Indonesia and ASEAN.

Mandala internal problems are also a challenge for Warwick. As known, formerly owned Mandala Kostrad, thick with the culture of military work. Of course, to change the culture of the army into a modern commercial organizations not work overnight. Warwick team to change the mindset of employees, starting with changing the top management. Top management ranks filled with people who have experience of international flights and combined with the Indonesian people with capability commercial business, so they can see the gap and the prospects for Indonesia's aviation market (Figure 1). Reshuffle was carried out since October 2007.

\begin{tabular}{|c|c|}
\hline $\begin{array}{c}\text { Steve Wilks } \\
\text { Chief Operating Officer }\end{array}$ & $\begin{array}{c}\text { - Previously : CEO DHL Aviation ME, Executive GM } \\
\text { Corporate Service of Air Niugini, GM of Air Nelson. }\end{array}$ \\
\hline $\begin{array}{c}\text { Irianda Susilo } \\
\text { Chief Commercial Officer }\end{array}$ & $\begin{array}{c}\text { - Previously as CEO Matahari Graha Fantasi, Unilever, } \\
\text { Mobil Oil }\end{array}$ \\
\hline Brian Bradbury & - Previously at British Airways, Bristows, Serco \& Gamco \\
\hline Technical Director & $\begin{array}{c}\text { - Previously as VP Financial Executive Cardig International, } \\
\text { IBRA }\end{array}$ \\
\hline Yadi Ruchandi & - Previously : Operational Director of Go Airlines, Airlines \\
Operational Director of Finnair, Niki and also Aero.
\end{tabular}

Figure 1 Top Management after reshuffle on October 2007 
With the formation of a new top management, then the next step undertaken by the CEO of Mandala is subject to change in the operational side of aviation, commercial strategy and improvement of human resources (Figure 2).

Operasional
- Rejuvenation of the
fleet by spending
about U.S. $\$ 1.89$
Billion to buy 30
New Fleet.
- Improvement of On
Time flight and
commitment with
schedule flight.
- Implementation
Safety Tools.
- Maintenance
aircraft with
Singapore Airlines
Engineering
Company.

Commercial
- Implementation
"easy book - easy to
pay" with ticket
booking system via
Navitaire that utilize
distribution
channels of the
website, call center
and sales of over 3
thousand more sales
agents
- Differsification with
flexible pricing but
not compete with
low cost carrier.
- Giving priority
routes, which
historically has a
loyal customer.

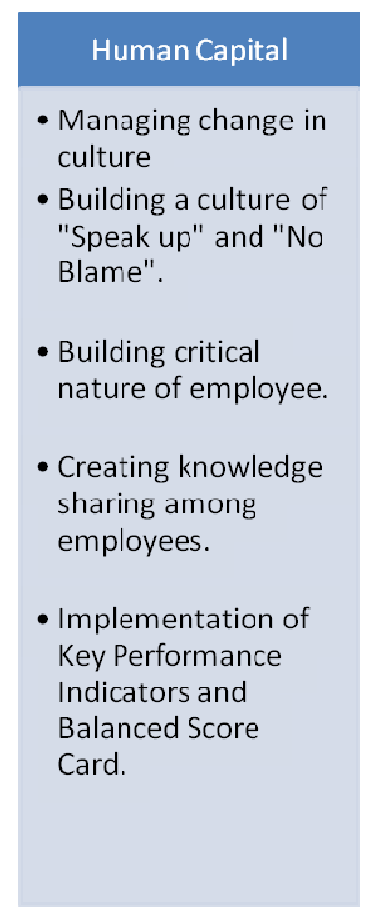

Figure 2 Strategy Transformation of New Mandala Airlines

While Mandala strategy to reach category 1 in this flight is to do a culture that focus to the safety factor, As said by Chief Executive Officer Warwick Brady, Mandala Airlines, "Culture for always oriented to safety factor must come from the TOP LEVEL with supported by a professional team consisting of international experts with experience in the field of 'Engineering \& Flight operations'. Chief Executive Officer, Warwick Brady said that, "Safety is handling of how to anticipate risks to ensure airlines to identify potential risks and take action to prevent the occurrence of 'incident \& accident'. All airlines in the world have experienced incident but the safest is to invest 'resources' are significant in terms of safety and take steps pro-active to anticipate risk.

Key personnel \& safety Management system

-Hiring an experienced professional team from various airlines worldwide.

-Every week 'Safety Board' perform data collection, assess and manage safety, security and quality of each fleet of aircraft.

\section{Airworthiness}

-Singapore Airlines Engineering Company (SIAEC) has been appointed to take care of all fleet aircraft AIRBUS.

-Appointed 12 experts from Malaysia and Singapore through the 'FD Aviation' to deal with Boeing. 


\section{Safety Management system}

- Chief Operating Officer is responsible for all operations Mandala and in particular to implement the 'safety system' to ensure 'a first class standard' which refers to

the international rules.

-Applying a 'Safety Net' and 'safety management system' to evaluate each incident.

-Implement a system called 'Airbus Flight Operation.

-Monitoring System (AirFase) to ensure that all aircraft be monitored and performance of each airplane can be accessed every day.

\section{Training}

- Training on 'safety and quality' has been done to all pilots, engineers and cabin crew.

-Establish a special training for all pilots Mandala.

\section{Quality \& Audits}

-Audit process to get certified IOSA (IATA Operational Safety Audit) to ensure

Mandala often refer to the international standard.

-Quality \& Audit Department has been formed to conduct audits in all areas of operation to ensure Mandala often refer to international standards.

\section{Commitment to Safety}

- Conduct campaigns to build a culture oriented to the 'safety system'.

-'Safety statement'- ensure open communication in informing the issues surrounding the problem of 'safety'.

Figure 3 Main Foundation Strategy of New Mandala Airlines to Achieve Category 1

During this transformation process underway, Warwick Brady, CEO of Mandala monitoring directly in the field to all existing units. And in the monitoring carried out, as the CEO of Mandala, he explains why companies must change and what will be and has been done. Almost all communication channels utilized by Warwick. All suggestions and criticism he received in the hope of transformation, which is conducted together this can be achieved with maximum results. Within a fairly fast after this transformation process, Mandala was transformed into the most innovative airline in 2007 and 2008. Mandala was awarded 'Best Airlines 1 / 2008 for Domestic Airlines category. "This gift is a form of appreciation from the PT (Persero) Angkasa Pura I Main Branch Ngurah Rai Airport.” Mandala Performance in the last 2 years showed a significant increase in the number of passengers or more than doubled in 2008 compared to the period of 2007.

\section{CONCLUSIONS}

After two years involved restructuring the operation to drive costs down and a fleet modernisation programme to replace a Boeing fleet with an all Airbus fleet, Warwick Brady successful bringing Mandala Airlines from a legacy brand into a modern, low cost carrier in the world's 4th most populous country, Indonesia. And at the end of February, Warwick Brady resigned as CEO of Mandala Airlines. Position Warwick Brady was replaced by Diono Nurjadin from Cardig International. Will Diono Nurjadin successfully continue the success of this transformation? How is the new CEO to create synergy and synchronization results interbreeding between domestic firms (Cardig International) with foreign companies (Indigo Partners) or in other words, how to unite the working culture between these two companies? 


\section{REFERENCES}

Aiken, C., \& Keller, S. (2006). The CEO's role in leading transformation. McKinsey \& Company.

Isren, J., Meaney, M. C., \& Wilson, S. (2009). Corporate transformation under pressure. McKinsey \& Company.

Mandala Airlines. (2007). BAGAIMANA MANDALA MEMPEROLEH KATEGORI 1? Langkahlangkah apa saja yang telah dilakukan untuk Transformasi NEW MANDALA, Press Release Mandala Airlines. Retrieved December 22, 2010, from Bagaimana Mandala Memperoleh Kategori 1?: http://www.mandalaair.com/docs/press/1235d66f-9bba-495c-a2329fabf6c434a9.pdf

Mandala Airlines. (2008). MANDALA tawarkan layanan Pemesanan untuk grup yang terintegrasi (Group Booking Solution), Press Release. Retrieved December 17, 2010, from Mandala Airlines: http://www.mandalaair.com/docs/press/bdce5e79-c9be-47f3-ae64-b2c9501a79f2.pdf

Mandala Airlines. (2009). Mandala terpilih sebagai maskapai penerbangan domestik terbaik di Denpasar. 26 Februari 2009. Retrieved December 20, 2010, from Mandala Airlines: http://www.mandalaair.com/mandala-news-detail.aspx?q=mdlbest

McKinsey \& Company. (2008). Creating organizational transformations: McKinsey Global Survey Results. McKinsey Quarterly .

Rahayu, E. M., \& Handayani, T. (2009). Transformasi Mandala Baru. Retrieved December 15, 2010, from MajalahSWA: http://202.59.162.82/swamajalah/praktik/details.php?cid=1\&id=8502

Wahyuni, A. I. (2009). CEO Mandala Warwick Brady Mundur. Retrieved December 22, 2010, from CEO Mandala Warwick Brady Mundur: http://www.detikfinance.com/read/2009/02/24/182118/1089919/4/ceo-mandala-warwickbrady-mundur 